\title{
Inhibition of Corrosion of Aluminium and its Alloys by Extracts of Green Inhibitors
}

\author{
M. Sangeetha, ${ }^{a, *}$ S. Rajendran, ${ }^{a, b}$ J. Sathiyabama ${ }^{a}$ and A. Krishnaveni ${ }^{c}$ \\ ${ }^{a} P G$ and Research Department of Chemistry, GTN Arts College, Dindigul ï 624005, \\ Tamil Nadu, India \\ ${ }^{b}$ Corrosion Research Centre, Department of Chemistry, RVS School of Engineering and \\ Technology, Dindigul ï 624005, India \\ ${ }^{c}$ Department of chemistry, Yadava College, Madurai, India
}

Received 21 November 2012; accepted 20 February 2013

\begin{abstract}
Aluminium is the most widely used non ferrous metal. It is very needful to prevent this metal from corrosion .Corrosion inhibitors are one of the widely used methods to control corrosion. The purpose of this paper is to make people aware of organic corrosion inhibitors. Organic inhibitors are mainly present in natural products. It has been found that plant extracts and natural products show inhibition efficiency up to $98 \%$. They are also non ï toxic, eco- friendly, very cheaper. In the present work, natural products are used at various conditions and their inhibition efficiency is calculated by different methods; they obey various adsorption isotherms; the protective films formed by the inhibitors are analyzed by techniques such as electrochemical methods, FTIR, HPLC-RP, SEM, EDS.
\end{abstract}

Keywords: aluminium, corrosion inhibition, plant extracts, green inhibitors.

\section{Introduction}

Aluminium or aluminium is a silvery white member of the boron group of chemical elements. It has the symbol $\mathrm{Al}$, and its atomic number is 13 . It is not soluble in water under normal circumstances. Aluminium is the third most abundant element (after oxygen and silicon) and the most abundant metal in the Earth's crust. It makes up about $8 \%$ by weight of the Earth's solid surface. Aluminium metal is too reactive chemically to occur natively. Instead, it is found combined in over 270 different minerals [1].

\footnotetext{
*Corresponding author. E-mail address: malathypush@yahoo.com
} 
The chief ore of aluminium is bauxite. The metal was first produced in 1825 (in an impure form) by Danish physicist and chemist Hans Christian Ørsted. Friedrich Wöhler conducted a similar experiment in 1827 by mixing anhydrous aluminium chloride with potassium and yielded aluminium [2].

Wöhler is generally credited with isolating aluminium (Latin alumen, alum), but also Ørsted can be listed as its discoverer [3]. Further, Pierre Berthier discovered aluminium in bauxite ore and successfully extracted it [4]. Charles Martin Hall of Ohio in the U.S. and Paul Héroult of France independently developed the HallHéroult electrolytic process that made extracting aluminium from minerals cheaper, being now the principal method used worldwide. Aluminium is a good thermal and electrical conductor, having $59 \%$ of the conductivity of copper, both thermal and electrical. Aluminium is capable of being a superconductor, with a superconducting critical temperature of $1.2 \mathrm{~K}$ and a critical magnetic field of about 100 Gauss (10 milliteslas) [5].

Aluminium is the most widely used non-ferrous metal [6]. Global production of aluminium in 2005 was 31.9 million tonnes. It exceeded that of any other metal except iron (837.5 million tonnes) [7]. Forecast for 2012 is $42 \ddot{i} 45$ million tons, driven by rising Chinese output [8]. The common aluminium foils and beverage cans are alloys of $92 \%$ to $99 \%$ aluminium [9].

Aluminium is $100 \%$ recyclable without any loss of its natural qualities. In Europe aluminium experiences high rates of recycling, ranging from $42 \%$ of beverage cans, $85 \%$ of construction materials and $95 \%$ of transport vehicles [10]. Corrosion resistance can be excellent due to a thin surface layer of aluminium oxide that forms when the metal is exposed to air, effectively preventing further oxidation. The strongest aluminium alloys are less corrosion resistant due to galvanic reactions with alloyed copper [11]. This corrosion resistance is also often greatly reduced when many aqueous salts are present, particularly in the presence of dissimilar metals.

\section{Natural corrosion inhibitors}

Noor has used an aqueous extract of Hibiscus sabdariffa leaves for inhibiting the corrosion of aluminum in alkaline solutions [12]. Chemical and electrochemical measurements were applied to evaluate the potential of aqueous extract of Hibiscus sabdariffa leaves (AEHSL) for inhibiting the corrosion of Al in $0.5 \mathrm{M}$ $\mathrm{NaOH}$. It was found that the inhibition efficiency increases with the increase of AEHSL concentration. Electrochemical measurements revealed that AEHSL acts as a mixed-type inhibitor with an inhibition category that belongs to geometric blocking. Adsorption of inhibitor species was found to follow Langmuir and Dubinin-Radushkevich isotherm models and the ability of AEHSL species to be adsorbed physically on the Al surface was illustrated by Dubinin-Radushkevich isotherm parameters. The data obtained from chemical and electrochemical measurements are in reasonably good agreement. Physical adsorption mechanism of AEHSl species on $\mathrm{Al}$ surface in $0.5 \mathrm{M} \mathrm{NaOH}$ becomes clear cut, by following the trend of inhibitor adsorption with solution temperature. Good correlation between AEHSL water-soluble constituents and the suggested physical 
adsorption mechanism was obtained. Moreover, at a certain concentration of AEHSL (1.00 $\left.\mathrm{g} \mathrm{L}^{-1}\right)$, the Al surface coverage increases with the increase of $\mathrm{NaOH}$ concentration up to $0.5 \mathrm{M}$ after which limited decrease was obtained with further increase in $\mathrm{NaOH}$ concentration.

Corrosion behaviour of aluminium in the presence of an aqueous extract of hibiscus rosa-sinensis has been evaluated by Rajendran et al. [13]. The inhibition efficiency (IE) of an aqueous extract of Hibiscus rosa-sinensis (white) in controlling corrosion of aluminium at $\mathrm{pH} 12$ has been evaluated by weight loss method in the absence and presence of $\mathrm{Zn}^{2+}$. The formulation consisting of $8 \mathrm{~mL}$ flower extract (FE) and $50 \mathrm{ppm}$ of $\mathrm{Zn}^{2+}$ had $98 \%$ inhibition efficiency. Polarization study revealed that this formulation functioned as a cathodic inhibitor. AC impedance spectra revealed the presence of a protective film formed on the metal surface. FTIR spectra revealed that the protective film consisted of a complex formed between the active principle of the flower extract and $\mathrm{Al}^{3+}$.

The corrosion inhibition of non toxic plant extract of Hibiscus Teterifa on the corrosion of chill cast $\mathrm{Al}-\mathrm{Zn}-\mathrm{Mg}$ alloy in 0.5 Molar solution of $\mathrm{NaOH}$ was studied using weight loss method [14]. The alloy of composition $4.5 \% \mathrm{Zn}, 2 \%$ $\mathrm{Mg}$ and balance $\mathrm{Al}$ was chill cast at the Foundry Shop of the National Metallurgical Development Centre, Jos, Nigeria. After casting, the alloy was cut and machined to corrosion coupons and immersed into $0.5 \mathrm{M}$ solution of $\mathrm{NaOH}$ containing varying concentrations of the inhibitor $(5-20 \% \mathrm{v} / \mathrm{v})$ at temperatures of 30, 50 and $70{ }^{\circ} \mathrm{C}$, respectively. It was found that the adsorption of Hibiscus Teterifa could prevent this alloy from weight loss and the adsorption accorded with the Langmuir adsorption isotherm. Thermodynamic parameters such as adsorption heat and adsorption free energy were obtained from experimental data. The kinetic data activation energy at different concentrations of the inhibitor was calculated. The most suitable range of inhibitor concentration was discussed. The inhibitive action was satisfactorily explained by using both thermodynamic and kinetic models. The mechanism of inhibition is that of physical adsorption and the adsorbed molecules of the inhibitor lies on the surface of the alloy blocking the active corrosion sites on the alloy hence, lowering the corrosion rate.

An interesting and efficient green corrosion inhibitor for aluminium from extracts of Chlomolaena odorata $L$. in acidic solution has been used by Obot and Obi-Egbedi [15]. The leaf extracts of Chromolaena odorata L. (LECO) has been studied as a possible source of green inhibitor for corrosion of aluminium in $2 \mathrm{M}$ $\mathrm{HCl}$ using gasometric and thermometric techniques at 30 and $60{ }^{\circ} \mathrm{C}$. Results obtained showed that the LECO functioned as an excellent corrosion inhibitor for aluminium in the acidic environment. Inhibition efficiency increased with extract concentration but decreased with temperature. The adsorption of LECO on Al surface is in accord with Langmuir adsorption isotherm. Both kinetic and thermodynamic parameters governing the adsorption process were calculated and 
discussed. From the experimental results obtained, it can be concluded that LECO, which are biodegradable, environmentally benign, and are obtained from a renewable resource with minimal health and safety concerns have the potential to be a cost effective alternative to synthetic corrosion inhibitors. This study provides new information on the inhibiting characteristics of LECO extract under specified conditions. The environmentally friendly inhibitor could find possible applications in metal surface anodizing and surface coating in industries.

The inhibition of corrosion of aluminum in hydrochloric acid solutions by the ethanolic extract of the leaves of Ananas sativum was studied using weight loss and hydrogen evolution methods [16]. It was found that the plant extract retarded the acid induced corrosion of aluminum. Inhibition efficiency increased with increasing concentration of the extract and temperature. Adsorption studies revealed that Langmuir adsorption isotherm is the best adsorption model applicable to the adsorption of A. sativum on aluminum surface. Activation parameters such as activation energies $\left(E_{a}\right)$, activation enthalpy, and activation entropy were evaluated from the effect of temperature on the corrosion and inhibition processes.

Synergistic and antagonistic effects of anions and ipomoea invulcrata as green corrosion inhibitor for aluminium dissolution in acidic medium have been investigated by Obot et al. [17]. The extract of Ipomoea invulcrata (IP) has been studied as a possible source of green inhibitor for corrosion of aluminium in $1 \mathrm{M}$ $\mathrm{HCl}$ at $30-60{ }^{\circ} \mathrm{C}$ using the conventional weight loss technique. The studies reveal that at constant acid concentration, the plant extract acts as an effective inhibitor for aluminium corrosion in acidic medium. Inhibition efficiency increases with concentration but decreases with increase in temperature and immersion time. The enhancement of inhibition efficiency of IP with the addition of KI and KSCN has also been studied. The apparent activation energy and the thermodynamic parameters governing the corrosion process have also been calculated. The adsorption of IP was in accord with the Langmuir adsorption isotherm at all the temperatures studied. The mechanism of physical adsorption is proposed for the inhibitory action of IP and is satisfactorily explained by both kinetic and thermodynamic parameters.

Anticorrosion behaviour of zenthoxylum alatum extract in acidic media has been investigated by Chauhan [18]. The commercial non-ionic surfactant plant used as a medicine, namely Zenthoxylum alatum was tested as inhibitor for the corrosion of copper and aluminium in $0.1 \mathrm{M}$ solution of $\mathrm{HCl}$. Weight loss measurement and potentiometry polarization technique were used in this study. It was found that this compound acts as a good inhibitor for the acid corrosion of copper and aluminium; the inhibition efficiencies obtained by the two techniques were almost the same, and increased with increasing the concentration of the inhibitors. The polarization technique shows that the compound acts as an inhibitor. The inhibition action of the surfactant is interpreted in view of the adsorption on the metal surface making a barrier to mass and charge transfer. It 
was found that the adsorption of the compound follows Langmuir adsorption isotherm. The values of free energy of adsorption for them were calculated. It was found that the adsorption process is spontaneous and increases, for the different surfactant, in the same direction as the inhibition efficiency.

The synergistic action caused by iodide ions on the corrosion inhibition of aluminium (Al) in $0.5 \mathrm{M} \mathrm{HCl}$ in the presence of Azadirachia Indica (AZI) plant extract has been investigated using potentiodynamic polarization and impedance techniques [19]. It is found that AZI extract inhibits the corrosion of aluminium in $0.5 \mathrm{M} \mathrm{HCl}$. The inhibition efficiency increases with the increase in AZI extract concentration, until $24 \% \mathrm{v} / \mathrm{v}$ of AZI extract, then Inh. $\%$ is decreased with father increase in AZI extract concentration. The adsorption of this extract in the studied concentration is found to obey Frewendlish adsorption isotherm. The addition of iodide ions enhances the inhibition efficiency to a considerable extent. The increase in inhibition efficiency (IE) \% values in presence of fixed concentration of iodide ions indicates that AZI extract forms an insoluble complex at lower AZI extract concentrations by undergoing a joint adsorption. But at higher concentrations of AZI extract, competitive adsorption is found between iodide ions and the formed complex leading to less (IE) \%. The (IE) \% further decreased in the presence of iodide ions with AZI extract than in presence of AZI extract alone at all studied iodide concentrations. The synergism parameter Sơis defined and calculated from surface coverage values. Synergism parameters have been calculated by other researchers also to investigate the synergistic effect [20-24].

Inhibition of aluminium corrosion in $2 \mathrm{M}$ sodium hydroxide solution in the presence and absence of $0.5 \mathrm{M} \mathrm{NaCl}$ using damsissa (Ambrosia maritime, L.) extract has been studied employing different chemical and electrochemical techniques [25]. Chemical gasometry technique showed that addition of chloride ions or damsissa extract to sodium hydroxide solution decreases the volume of the hydrogen gas evolved. Potentiodynamic results manifested that chloride ion retard the anodic dissolution of aluminium, below the pitting potential, in sodium hydroxide solution. Damsissa extract, in presence or absence of chloride ion, influenced both the anodic dissolution of aluminium and the generated hydrogen gas at the cathode indicating that the extract behaved as a mixed-type inhibitor. The decrease in the observed limiting current with increasing damsissa extract concentration indicated that the anodic process is controlled by diffusion. Nyquist plots present two capacitive semicircles at higher and lower frequencies separated by an inductive loop at intermediate frequencies. The inductive loops were clarified by the occurrence of adsorbed intermediates on the surface. A proposed equivalent circuit was used to analyze the impedance spectra for aluminium in alkaline solutions. The results showed that the damsissa extract could serve as an effective inhibitor for the corrosion of aluminium in alkaline solutions. The impedance measurements verified the remarkable stability of the extracts during storage up to 35 days. Damsissa extract was found more effective in presence of chloride ions than in its absence. Inhibition was found to increase 
with increasing the concentration of the extract but decreases with increasing temperature. The associated activation parameters have been determined and discussed.

Adsorption and corrosive inhibitive properties of Vigna unguiculata in alkaline and acidic media have been reported by Umoren et al. [26].The main objective of the work was to investigate the adsorption behaviour and inhibitive effect of Vigna unguiculata (VU) extract (agricultural waste material) for aluminium corrosion in $0.5 \mathrm{M} \mathrm{NaOH}$ and $\mathrm{H}_{2} \mathrm{SO}_{4}$. The inhibitive effect of the plant extract was assessed using weight loss method at 30 and $60{ }^{\circ} \mathrm{C}$. The trend of inhibition efficiency with temperature was used to propose the mechanism of inhibition and type of adsorption. VU extract effectively inhibited aluminium corrosion in both alkaline and acidic media. Inhibition efficiency (I \%) of the extract increased with increase in concentration of the extract and temperature. Inhibitor adsorption characteristics were approximated by Freundlich and Temkin adsorption isotherms at all the concentrations and temperatures studied. The phenomenon of chemical adsorption is proposed from the activation parameters obtained. Research limitations/implications - The mechanistic aspect of the corrosion inhibition can be better understood using electrochemical studies such as polarization and $\mathrm{AC}$ impedance spectra. The findings may be useful in metal surface anodizing and metal coating.

The inhibition efficiency of an aqueous extract of garlic in controlling corrosion of aluminium immersed in sodium hydroxide solution at $\mathrm{pH} 11$ and 12, in the absence and presence of $\mathrm{Zn}^{2+}$, was evaluated by the weight loss method [27]. At $\mathrm{pH} \mathrm{11,} \mathrm{the} \mathrm{extract} \mathrm{accelerated} \mathrm{corrosion} \mathrm{of} \mathrm{aluminium} \mathrm{in} \mathrm{the} \mathrm{absence} \mathrm{and}$ presence of $\mathrm{Zn}^{2+}$. The influences of $\mathrm{N}$-cety|-N,N,N- trimethylammonium bromide (CATB) (a biocide and a cationic surfactant) and immersion period on the inhibition efficiency were investigated. The influence of sodium sulphite, an oxygen scavenger, on the inhibition efficiency of the inhibitor system revealed that the transport of the inhibitor towards the metal surface plays a greater role than the removal of oxygen from the aqueous solution in determining the inhibition efficiency of the system. The protective film was analysed with the use of Fourier transform infrared spectra. Corrosion inhibition of aluminum in hydrochloric acid solutions by peepal (Ficus Religeosa) extracts has been evaluated by Chowdhary et al. [28]. Mass loss and thermometric methods have been used to study the inhibition of aluminum corrosion in $\mathrm{HCl}$ solutions by extracts of different parts of Peepal (Ficus Religeosa). Values of inhibition efficiency obtained by the two methods are in good agreement and are dependent upon the concentrations of the inhibitor and the acid.

The corrosion inhibition of aluminium in $\mathrm{HC} 1$ in the presence of Carica papaya (CP) and Azadirachta indica (AI) at $30-40{ }^{\circ} \mathrm{C}$ was studied using the weight loss, thermometric and hydrogen evolution techniques [29]. The inhibition efficiency (\% I) increased with increase in concentration of the extracts and with increase in temperature. $\mathrm{CP}$ is a better inhibitor at $30{ }^{\circ} \mathrm{C}$, whereas $\mathrm{AI}$ is better at $40{ }^{\circ} \mathrm{C}$. CP 
and AI were found to obey Freundlich, Temkin and Flory -Huggins adsorption isotherms at all concentrations studied at $40{ }^{\circ} \mathrm{C}$. Phenomenon of chemical adsorption is proposed from the obtained $\mathrm{E}_{\mathrm{a}}, \mathrm{q}_{\mathrm{ads}}$ and $\mathrm{Q}_{\mathrm{ads}}$ values calculated.

Inhibition of aluminum corrosion using Opuntia extract has been investigated by EL-Etre [30]. The inhibitive action of the mucilage extracted from the modified stems of prickly pears, toward acid corrosion of aluminum, is tested using weight loss, thermometry, hydrogen evolution and polarization techniques. It was found that the extract acts as a good corrosion inhibitor for aluminum corrosion in 2.0 $\mathrm{M} \mathrm{HCl}$ solution. The inhibition action of the extract was discussed in view of Langmuir adsorption isotherm. It was found that the adsorption of the extract on aluminum surface is a spontaneous process. The inhibition efficiency (IE) increases as the extract concentration is increased. The effect of temperature on the IE was studied. It was found that the presence of extract increases the activation energy of the corrosion reaction. Moreover, the thermodynamic parameters of the adsorption process were calculated. It was found also that the Opuntia extract provides a good protection to aluminum against pitting corrosion in chloride ion containing solutions.

Corrosion control by water-soluble extracts from leaves of economic plants has been studied by Rehan [31]. Water extracts from leaves of date palm, phoenix dactylifera, henna, Lawsonia inermis, and corn, Zea mays, were tested as corrosion inhibitors for steel, aluminum, copper and brass in acid chloride and sodium hydroxide solutions using weight loss, solution analysis and potential measurements. The inhibition action was found to critically depend on metal type and solution composition. Only, date palm and henna extracts were found highly effective in reducing corrosion rate of steel in acid chloride solutions and aluminum in sodium hydroxide solutions. The inhibition efficiency increased with increasing the concentration of the extract. The inhibition was interpreted in terms of chemisorption of some active ingredients in the leaves according to Temkin isotherm.

Inhibition of corrosion of the Al-2.5Mg alloy by means of the third acidic phenolic subfraction of aqueous extract of Rosemary. Radosevic et al. have examined the possibility of inhibition of corrosion of the Al-2.5Mg alloy in deaerated $\mathrm{w}=3 \% \mathrm{NaCl}$ solution at $25{ }^{\circ} \mathrm{C}$, by the means of the third acidic phenolic subfraction of the aqueous extract of Rosemary leaves [32]. The polyphenolic constituents were extracted from the plant material with water (maceration $6 \mathrm{~h}$, room temperature). The raw extract was purified by means of diethyl ether. Fractionation into acidic and neutral phenolic compounds was carried out on Sep Pak C18 cartridges (Waters Associates, Milford, MA, USA). The ferulic acid was identified by its retention time, using the external standard method. The measurements were performed in the electrochemical glass cell of the usual type with a platinum counter electrode and a saturated calomel electrode in contact with working electrode via Luggin capillary. The additives were added in varying concentrations (from $1 \times 10^{-6}$ to $1 \times 10^{-3} \mathrm{~mol} \mathrm{dm}^{-3}$ ) to the 
basic solution. Potentiodynamic polarization curves were produced using a potentiostat (PAR M273) with scanning rate of $2 \mathrm{mV} \mathrm{s}^{-1}$. Anodic and cathodic branches of the polarization curves were recorded and joined into a Tafel diagram. The least squares method was used to extrapolate Tafel straight lines and to determine the electrochemical parameters. High-pressure liquid chromatography in the reverse phase (HPLC-RP) has been used to examine the composition of the third subfraction and it has confirmed that it consists of ferulic acid. Experiments on the commercial ferulic acid were also made. The potentiodynamic polarization measurements suggest that ferulic acid is responsible for the inhibition action of the third acidic phenolic subfraction of the aqueous extract of rosemary. From the polarization curves may be deduced that the third acidic phenolic subfraction acts as a cathodic type corrosion inhibitor. The results have indicated that the inhibitor adsorbs on the alloy surface according to Freundlich adsorption isotherm, and the values obtained for the standard free energy of adsorption indicate physical adsorption.

Economic losses due to corrosion are direct, as well as indirect and affect the economy of all the countries. Corrosion inhibitors are one of the widely used methods to control corrosion. Particular advantage of the corrosion inhibitor is that it can often be implemented or changed in the situation without disturbing the process. Due to toxic nature and high cost of some inhibitors currently in use it is nearly to develop environmentally acceptable and less expensive inhibitors. Natural products can be considered as a good source for this purpose. An evaluation of effective performance of seed extract of abrusprecatorius on corrosion inhibition of aluminium in sodium hydroxide at ambient temperature has been made by Rajalakshmi et al. [33]. Conventional weight loss and polarization measurement techniques were used for evaluation. Surface coverage values were tested graphically for suitable adsorption isotherms.

Obot and Obi- Egbedi have reported the inhibitive action of the root of ginseng on aluminium corrosion in $\mathrm{HCl}$ solution using weight loss method at $30-60{ }^{\circ} \mathrm{C}$ [34]. Results obtained showed that ginseng root functioned as an effective and excellent inhibitor in the acid medium. Corrosion rate increased both in the absence and presence of the inhibitor with increase in temperature. Corrosion rate was also found to decrease in the presence of the inhibitor compared to the free acid solution. Inhibition efficiency increases with increase in concentration of the inhibitor but decreases with increase in temperature, reaching a maximum of $93.1 \%$ at $30{ }^{\circ} \mathrm{C}$ at $50 \% \mathrm{v} / \mathrm{v}$ concentration of ginseng. Addition of iodide ions to the root extracts of ginseng enhances the inhibition efficiency considerably and the effect is more pronounced at higher temperatures. The adsorption of extract components onto the aluminium surface was found to be a spontaneous process and to follow the Freundlich adsorption isotherm. The free energies, enthalpy and entropy for the adsorption process as well as the energy of activation, enthalpy of activation and entropy of activation for the dissolution process were determined and discussed. A mechanism of physical adsorption of the root components on the surface of the metal is proposed for the inhibition behavior. 
SEM-EDS Characterization of Natural Products on Corrosion Inhibition of Alī Mgī Si Alloy has been studied by R. Rosliza and S. Izman [35] .The corrosion resistance of aluminum and its alloys is the subject of tremendous technological importance due to their increased industrial applications. The corrosion protections and the mechanism of corrosion inhibitions of natural products for an Alī Mgī Si alloy in seawater were investigated at room temperature. The surface morphology was studied by means of macro scale electrochemical techniques and localized microscopic methods, i.e., Scanning Electron Microscope (SEM) with associated elemental analysis by Energy Dispersive Spectrometer (EDS). SEM examinations provided morphological characterization of the surface of Alī Mgī Si alloy sample before and after immersion in seawater; meanwhile surface analytical techniques by the EDS allowed us to investigate detail the chemical composition of aluminum oxide layers. The experiments were performed with Alī Mgī Si alloy, immersed in a 5 $\mathrm{L}$ beaker containing seawater with and without the natural products for 60 days at room temperature. The SEM results indicate that the natural products (natural honey, vanillin, and tapioca starch) absolutely inhibited the corrosion products on the specimen surfaces. They also protected the passive film from dissolution in seawater. The EDS spectra have determined carbonaceous, carbonyl, methoxy and hydroxyl groups as functional groups of natural products in the inhibition mechanism.

The use of natural products as corrosion inhibitors in preventing corrosion of aluminium, is summarized in Table 1.

Table 1. Inhibition of corrosion of aluminium by natural products.

\begin{tabular}{|c|c|c|c|c|c|c|c|}
\hline No & Metal & Medium & Inhibitor & Additive & Method & Findings & Ref \\
\hline 1 & $\overline{\mathrm{Al}}$ & $\begin{array}{l}0.5 \mathrm{M} \\
\mathrm{NaOH}\end{array}$ & $\begin{array}{c}\text { Hibiscus sabdariffa } \\
\text { leaves (AEHSL) }\end{array}$ & & $\begin{array}{l}\text { Electrochemical } \\
\text { measurements }\end{array}$ & $\begin{array}{l}\text { mixed-type inhibitor } \\
\text { Langmuir and Dubinin- } \\
\text { Radushkevich isotherm }\end{array}$ & 12 \\
\hline 2 & $\begin{array}{c}\text { Al at } \mathrm{pH} \\
12\end{array}$ & & $\begin{array}{l}\text { Hibiscus rosa- } \\
\text { sinensis (white) }\end{array}$ & $\mathrm{Zn}^{2+}$ & $\begin{array}{l}\text { weight loss method, } \\
\text { AC impedance and } \\
\text { FTIR methods }\end{array}$ & cathodic inhibitor & 13 \\
\hline 3 & $\begin{array}{l}\text { chill } \\
\text { cast } \mathrm{Al}- \\
\mathrm{Zn}-\mathrm{Mg} \\
\text { alloy }\end{array}$ & $\begin{array}{l}0.5 \mathrm{M} \\
\mathrm{NaOH}\end{array}$ & Hibiscus Teterifa & & $\begin{array}{c}\text { weight loss Langmuir } \\
\text { adsorption isotherm. } \\
\text { And Thermodynamic } \\
\text { studies, temperatures } \\
\text { of } 30,50 \text { and } 70^{\circ} \mathrm{C} \\
\text { respectively }\end{array}$ & $\begin{array}{l}\text { the adsorbed molecules } \\
\text { of the inhibitor lie on } \\
\text { the surface of the alloy } \\
\text { blocking the active } \\
\text { corrosion sites on the } \\
\text { alloy hence, lowering } \\
\text { the corrosion rate. }\end{array}$ & 14 \\
\hline 4 & $\mathrm{Al}$ & $2 \mathrm{M} \mathrm{HCl}$ & $\begin{array}{c}\text { Chromolaena } \\
\text { odorata L. (LECO) }\end{array}$ & & $\begin{array}{c}\text { gasometric and } \\
\text { thermometric } \\
\text { techniques. Temp 30- } \\
60{ }^{\circ} \mathrm{C}\end{array}$ & $\begin{array}{l}\text { Langmuir adsorption } \\
\text { isotherm, applications } \\
\text { on metal surface } \\
\text { anodizing and surface } \\
\text { coating in industries. }\end{array}$ & 15 \\
\hline 5 & $\mathrm{Al}$ & $\mathrm{HCl}$ & $\begin{array}{c}\text { ethanolic extract of } \\
\text { the leaves of } \\
\text { Ananas sativum }\end{array}$ & & $\begin{array}{l}\text { weight loss and } \\
\text { hydrogen evolution } \\
\text { methods }\end{array}$ & $\begin{array}{l}\text { Langmuir adsorption } \\
\text { isotherm, activation } \\
\text { energies }\left(\mathrm{E}_{\mathrm{a}}\right) \text {, activation } \\
\text { enthalpy }\left(\alpha^{\circ}\right) \text {, and } \\
\text { activation entropy }(q \beta)\end{array}$ & 16 \\
\hline 6 & $\mathrm{Al}$ & $1 \mathrm{M} \mathrm{HCl}$ & $\begin{array}{l}\text { Ipomoea invulcrata } \\
\text { (IP) }\end{array}$ & & $\begin{array}{l}\text { weight loss technique, } \\
\text { kinetic and } \\
\text { thermodynamic } \\
\text { techniques. Temp 30- } \\
60^{\circ} \mathrm{C} \text {, KI and KSCN }\end{array}$ & $\begin{array}{l}\text { Langmuir adsorption } \\
\text { isotherm }\end{array}$ & 17 \\
\hline
\end{tabular}




\begin{tabular}{|c|c|c|c|c|c|c|c|}
\hline 7 & $\begin{array}{l}\text { copper } \\
\text { and } \mathrm{Al}\end{array}$ & $0.1 \mathrm{M} \mathrm{HCl}$ & $\begin{array}{l}\text { Zenthoxylum } \\
\text { alatum }\end{array}$ & & $\begin{array}{c}\text { Weight loss } \\
\text { measurement and } \\
\text { potentiometry } \\
\text { polarization technique }\end{array}$ & $\begin{array}{l}\text { Langmuir adsorption } \\
\text { isotherm }\end{array}$ & 18 \\
\hline 8 & $\mathrm{Al}$ & $0.5 \mathrm{M} \mathrm{HCl}$ & $\begin{array}{l}\text { Azadirachia Indica } \\
\text { (AZI) plant }\end{array}$ & iodide ions & $\begin{array}{c}\text { potentiodynamic } \\
\text { polarization and } \\
\text { impedance techniques }\end{array}$ & $\begin{array}{l}\text { Freundlish adsorption } \\
\text { isotherm }\end{array}$ & 19 \\
\hline 9 & $\mathrm{Al}$ & $\begin{array}{c}0.5 \mathrm{M} \\
\mathrm{NaCl}_{2} \mathrm{M} \\
\text { sodium } \\
\text { hydroxide }\end{array}$ & $\begin{array}{c}\text { damsissa (Ambrosia } \\
\text { maritime, L.) }\end{array}$ & & $\begin{array}{c}\text { electrochemical } \\
\text { techniques. Chemical } \\
\text { gasometry technique }\end{array}$ & mixed-type inhibitor & 25 \\
\hline 10 & $\mathrm{Al}$ & $\begin{array}{c}0.5 \mathrm{M} \\
\mathrm{NaOH} \text { and } \\
\mathrm{H}_{2} \mathrm{SO}_{4}\end{array}$ & $\begin{array}{l}\text { Vigna unguiculata } \\
\text { (VU) extract } \\
\text { (agricultural waste } \\
\text { material) }\end{array}$ & & $\begin{array}{c}\text { weight loss method } \\
\text { electrochemical } \\
\text { studies. Temp } 30 \text { and } \\
60^{\circ} \mathrm{C}\end{array}$ & $\begin{array}{l}\text { Freundlich and Temkin } \\
\text { adsorption isotherms, } \\
\text { anodic inhibitor }\end{array}$ & 26 \\
\hline 11 & $\begin{array}{c}\mathrm{Al}(\mathrm{pH} \\
11 \text { and } \\
12) \\
\end{array}$ & $\mathrm{NaOH}$ & $\begin{array}{l}\text { aqueous extract of } \\
\text { garlic }\end{array}$ & $\begin{array}{c}\mathrm{Zn}^{2+}(\mathrm{CTAB}) \\
\text { sodium } \\
\text { sulphite } \\
\end{array}$ & $\begin{array}{c}\text { weight loss method, } \\
\text { FTIR. }\end{array}$ & $\begin{array}{l}\text { The protective film was } \\
\text { analysed }\end{array}$ & 27 \\
\hline 12 & $\mathrm{Al}$ & $\mathrm{HCl}$ & $\begin{array}{l}\text { Peepal (Ficus } \\
\text { Religeosa). }\end{array}$ & & $\begin{array}{l}\text { Mass loss and } \\
\text { thermometric methods }\end{array}$ & $\begin{array}{l}\text { IE dependent upon the } \\
\text { concentrations of the } \\
\text { inhibitor and the acid. }\end{array}$ & 28 \\
\hline 13 & $\mathrm{Al}$ & $\mathrm{HCl}$ & $\begin{array}{l}\text { Carica papaya }(\mathrm{CP}) \\
\text { and Azadirachta } \\
\text { indica }(\mathrm{AI})\end{array}$ & & $\begin{array}{c}\text { weight loss, } \\
\text { thermometric and } \\
\text { hydrogen evolution } \\
\text { techniques. Temp } 30- \\
40^{\circ} \mathrm{C}\end{array}$ & $\begin{array}{c}\text { Freundlich, Temkin and } \\
\text { Flory -Huggins } \\
\text { adsorption isotherms } \\
\mathrm{E}_{\mathrm{a}}, q_{\mathrm{ads}} \text { and } \\
\mathrm{Q}_{\mathrm{ads}} \text { values calculated }\end{array}$ & 29 \\
\hline 14 & $\mathrm{Al}$ & $2.0 \mathrm{M} \mathrm{HCl}$ & $\begin{array}{l}\text { the mucilage } \\
\text { extracted from the } \\
\text { modified stems of } \\
\text { prickly } \\
\text { pears,(opuntia) }\end{array}$ & & $\begin{array}{l}\text { weight loss, } \\
\text { thermometry, } \\
\text { hydrogen evolution } \\
\text { and polarization } \\
\text { techniques }\end{array}$ & $\begin{array}{l}\text { Langmuir adsorption } \\
\text { isotherm, } \\
\text { thermodynamic } \\
\text { parameters were } \\
\text { calculated }\end{array}$ & 30 \\
\hline 15 & $\begin{array}{l}\text { aluminu } \\
\text { m, } \\
\text { copper } \\
\text { and } \\
\text { brass }\end{array}$ & $\begin{array}{c}\text { acid } \\
\text { chloride } \\
\text { and } \\
\text { sodium } \\
\text { hydroxide }\end{array}$ & $\begin{array}{l}\text { leaves of date palm, } \\
\text { phoenix dactylifera, } \\
\text { henna, Lawsonia } \\
\text { inermis, and corn }\end{array}$ & & $\begin{array}{l}\text { weight loss, solution } \\
\text { analysis and potential } \\
\text { measurements }\end{array}$ & $\begin{array}{l}\text { Temkin isotherm, date } \\
\text { palm and henna extracts } \\
\text { were found highly } \\
\text { effective in reducing } \\
\text { corrosion rate of steel in } \\
\text { acid chloride solutions } \\
\text { and aluminum in } \\
\text { sodium hydroxide } \\
\text { solutions }\end{array}$ & 31 \\
\hline 16 & $\begin{array}{l}\mathrm{Al}- \\
2.5 \mathrm{Mg} \\
\text { alloy }\end{array}$ & $3 \% \mathrm{NaCl}$ & $\begin{array}{c}\text { the third acidic } \\
\text { phenolic subfraction } \\
\text { of Rosemary leaves } \\
\text { extract }\end{array}$ & & $\begin{array}{l}\text { Potentiodynamic } \\
\text { polarization curves. } \\
\text { High-pressure liquid } \\
\text { chromatography in } \\
\text { the reverse phase } \\
\text { (HPLC-RP). Temp } 25 \\
{ }^{\circ} \mathrm{C}\end{array}$ & $\begin{array}{l}\text { ferulic acid is } \\
\text { responsible for the } \\
\text { inhibition action of the } \\
\text { third acidic phenolic } \\
\text { subfraction of the } \\
\text { aqueous extract of } \\
\text { rosemary, cathodic type } \\
\text { corrosion inhibitor, } \\
\text { Freundlich adsorption } \\
\text { isotherm }\end{array}$ & 32 \\
\hline 17 & $\mathrm{Al}$ & $\mathrm{NaOH}$ & abrusprecatorius & ambient temp & $\begin{array}{l}\text { weight loss and } \\
\text { polarization } \\
\text { techniques }\end{array}$ & $\begin{array}{c}\text { suitable adsorption } \\
\text { isotherms were tested } \\
\text { graphically } \\
\end{array}$ & 33 \\
\hline 18 & $\mathrm{Al}$ & $1 \mathrm{M} \mathrm{HCl}$ & root of ginseng & & $\begin{array}{c}\text { weight loss } \\
\text { techniques. Temp 30- } \\
60^{\circ} \mathrm{C} \text {. }\end{array}$ & $\begin{array}{l}\mathrm{IE} 93.1 \% \text { at } 30^{\circ} \mathrm{C} \text { at } 50 \\
\% \text { v/v concentration of } \\
\text { ginseng. Freundlich } \\
\text { adsorption isotherm, } \\
\text { thermodynamic } \\
\text { parameters calculated }\end{array}$ & 34 \\
\hline 19 & $\begin{array}{l}\text { Alī Mgī } \\
\text { Si alloy }\end{array}$ & & natural products & room temp & $\begin{array}{l}\text { Scanning electron } \\
\text { microscope (SEM) } \\
\text { with (EDS) }\end{array}$ & $\begin{array}{c}\text { SEM examinations } \\
\text { provided morphological } \\
\text { characterization of the } \\
\text { surface of } \mathrm{Alī} \mathrm{Mg} \mathrm{I} \mathrm{Si} \\
\text { alloy }\end{array}$ & 35 \\
\hline
\end{tabular}




\section{References}

1. Shakhashiri BZ. Chemical of the Week: Aluminum. Science is Fun. 2007 Aug 28.

2. Bentor Y. Periodic Table: Aluminum. ChemicalElements.com. 2007 Aug 11.

3. Berthier P. Today in Science History. 2007 Aug 11.

4. Deville HES-C. De l'aluminium, ses propriétés, sa fabrication. Paris; 1859.

5. Cochran JF, Mapother DE. Superconducting transition in aluminum. Phys Rev. 1958;111:132-142.

6. Aluminium. Encyclopædia Britannica.

7. Hetherington LE, Brown TJ, Benham AJ, Lusty PAJ, Idoine NE. World mineral production 2001-2005. British Geological Survey; 2007.

8. Rising Chinese Costs to Support Aluminum Prices. Bloomberg News. 2009 Nov 23.

9. Millberg LS. Aluminum Foil. How Products are Made. 2007 Aug 11.

10. Reciclado del aluminio. Confemetal.es ASERAL.

11. Polmear IJ. Light alloys: metallurgy of the light metals. Arnold; 1995.

12. Noor EA. Potential of aqueous extract of Hibiscus sabdariffa leaves for inhibiting the corrosion of aluminum in alkaline solutions. J Appl Electrochem. 2009;39:1465-1475.

13. Rajendran S, Jeyasundari J, Usha P, Selvi JA, Narayanasamy B, Regis APP, Rengan P. Corrosion behaviour of aluminium in the presence of an aqueous extract of hibiscus rosa-sinensis. Port Electrochim Acta. 2009;27:153-164.

14. Ayeni FA, Aigbodion VS. Non-toxic plant extract as corrosion inhibitor for hill cast Al-Zn-Mg alloy in caustic soda solution. Eurasian ChemicoTechnol J. 2007;9:91-96.

15. Obot IB, Obi-Egbedi NO. An interesting and efficient green corrosion inhibitor for aluminium from extracts of Chlomolaena odorata L. in acidic solution. J Appl Electrochem. 2010;40:1977-1984.

16. Ating EI, Umoren SA, Udousoro II, Ebenso EE, Udoh AP. Leaves extract of ananas sativum as green corrosion inhibitor for aluminium in hydrochloric acid solutions. Green Chem Lett Rev. 2010;3:61-68.

17. Obot IB, Obi-Egbedi NO, Umoren SA, Ebenso EE. Synergistic and antagonistic effects of anions and ipomoea invulcrata as green corrosion inhibitor for aluminium dissolution in acidic medium. Int $\mathbf{J}$ Electrochem Sci. 2010;5:994-1007.

18. Chaühan JS. Anticorrosion behaviour of zenthoxylum alatum extract in acidic media. Asian J Chem. 2009;21:1975-1978.

19. Arab ST, Al-Turkustani AM, Al-Dhahiri RH. Synergistic effect of Azadirachta Indica extract and iodide ions on the corrosion inhibition of aluminium in acid media. J Korean Chem Soc. 2008;52:281-294.

20. Njoku VO, Oguzie EE. Inhibitory properties of Baphia nitida extract in acid mild steel corrosion. Eur Corros Congress ï EUROCORR. 2009;2:849-870. 
21 Rajenderan S, Shanmugapriya S, Rajalakshmi T, Amal Raj AJ. Corrosion inhibition by an aqueous extract of rhizome powder. Corrosion. 2005;61:685-692.

22. Kumar TE, Vishwanatham S, Udayabhanu G. Synergistic effects of formaldehyde and alcoholic extract of plant leaves for protection of N80 steel in 15\% HCl. Corrosion Eng Sci Tech. 2004;39:327- 332.

23. Rajendran S, Agasta M, Bama devi R, Shyamala devi B, Rajam K, Jeyasundari J. Corrosion inhibition by an aqueous extract of Henna leaves (Lawsonia Inermis L). Zastita Materijala. 2009;50:77-84.

24. Sherine HB, Nasser AJA, Rajendran S. m-Nitrophenol as a corrosion inhibitor for carbon steel. J Electro Chem Soc India. 2009;58:30-36.

25. Abdel-Gaber AM, Khamis E, Abo-El Dahab H, Adeel, Sh. Inhibition of aluminium corrosion in alkaline solutions using natural compound. Mater Chem Phys. 2008;109:297-305.

26. Umoren SA, Obot IB, Akpabio LE, Etuk SE. Adsorption and corrosive inhibitive properties of Vigna unguiculata in alkaline and acidic media. Pigment Resin Tech. 2008;37:98-105.

27. Priya SL, Chitra A, Rajendran S, Anuradha K. Corrosion behaviour of aluminium in rain water containing garlic extract. Surf Eng. 2005;21:229231.

28. Jain T, Chowdhary R, Arora P, Mathur SP. Corrosion inhibition of aluminum in hydrochloric acid solutions by peepal (Ficus Religeosa) extracts. Bull Electrochem. 2005;21:23-27.

29. Ebenso EE, Ibok UJ, Ekpe U.J, Umoren S, Jackson E, Abiola OK, Oforka NC, Martinez S. Corrosion inhibition studies of some plant extracts on aluminium in acidic medium. Transactions SAEST. 2004;39:117-123.

30. El-Etre AY. Inhibition of aluminum corrosion using Opuntia extract. Corrosion Sci. 2003;45:2485-2495.

31. Rehan HH. Corrosion control by water-soluble extracts from leaves of economic plants. Materialwissenschaft Werkstofftechnik. 2003;34:232-237.

32. Radoǵevil J, Kliǵkil M, Viǵekruna A. Inhibition of corrosion of the Al$2.5 \mathrm{Mg}$ alloy by means of the third acidic phenolic subfraction of aqueous extract of Rosemary. J Chem Chem Eng. 2001;50:537-541.

33. Rajalakshmi R, Subhashini S, Nanthini M, Srimathi M. Inhibiting effect of seed extract of Abrus precatorius on corrosion of aluminium in sodium hydroxide. Oriental J Chem. 2009;25:313-318.

34. Obot I.B, Obi-Egbedi NO. Ginseng root: A new efficient and effective ecofriendly corrosion inhibitor for aluminium alloy of type AA 1060 in hydrochloric acid solution. Int J Electrochem Sci. 2009;4:1277-1288.

35. Rosliza R, Izman S. SEM_EDS Characterization of Natural Products on Corrosion Inhibition of Alī Mgī Si Alloy. Protec Metals Phys Chem Surf. 2011;47:395-401. 